\title{
Editorial - a plea for changing directions of public sector accounting research in emerging economies
}

\section{Introduction}

The pandemic and the financial crisis of 2008 have demonstrated the importance of governments' involvement in protecting the lives and livelihoods of citizens. At the same time, an unprecedented increase in the volume of government expenditures has, however, raised concerns over the capacity of governments to meet their future socio-environmental and financial obligations, and has ultimately questioned the long-term sustainability of public finance. The financial health of governments has therefore drawn wider attention (World Bank, 2020). However, even before the pandemic and the crisis, public sector institutions' way of utilising public funds has been subject to public and media scrutiny (Gårseth-Nesbakk and Kuruppu, 2018). Throughout the past decades, countries aspired to increase public sector institutions' efficiency and effectiveness, and to avoid corruption by adopting business-like practices (Hood, 1991a, b, 1995). In particular, a greater effort has been made to quantify results and outcomes concerned with the use of public funds and resources, predicating improvements in the allocation of scarce resources and better public service delivery (Hood, 1995; Torfing and Traintafillou, 2014). Such initiatives, central to new public management (NPM), are often claimed to be an ideal way to reinvent the public sector (Torfing and Traintafillou, 2014).

An important issue of debate raised by NPM was the role of accounting systems in managing the public sector. Conventional cash-based accounting was claimed to be inadequate to generate information to visualise existing inefficiencies in the public sector (Christensen and Parker, 2010; Hellstrom and Lapsley, 2016). Governments in Anglo-Saxon countries were at the forefront in terms of transition towards accrual accounting (Christensen and Parker, 2010; Hyndman et al, 2014) and performance auditing (Gårseth-Nesbakk and Kuruppu, 2018). International institutions such as the United Nations (UN) and the World Bank demanded that developing countries should adopt an accounting system that would enable them to monitor efficiency and track development expenditures (Dean, 1989). The UN published a report on accrual accounting in developing countries to facilitate the process of introducing a new accounting system (UN, 1984). In later years, the idea of accrual accounting was picked up by the World Bank having reckoned it to be the best accounting practice. As demonstrated by the literature, the trend of adopting accrual accounting has certainly gained ground in emerging economies (EEs) (Van Helden and Uddin, 2016; Adhikari et al., 2019).

In the process of problematising cash-based accounting and inefficiencies in the public sector, management consultants and professional accountants have appeared to be the key facilitators, not only in developed countries (Christensen and Skærbæk, 2010; Hellstrom and Lapsley, 2016) but also in EEs (Adhikari et al., 2013, 2015, 2019). The literature shows that a lack of awareness of these consultants with regard to local contexts and the self-interest of professional accountants have very often resulted in unintended consequences in public sector accounting reforms (Christensen et al., 2019; Jayasinghe et al., 2021). The editorial of this special issue aims at shedding light on unintended consequences of NPM reforms that foster customer-like relationships and pinpointing the importance of initiating collaboration

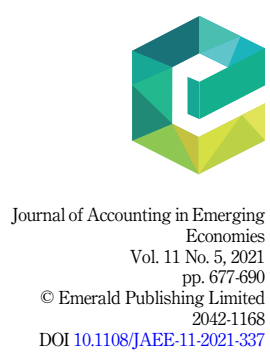


JAEE 11,5

between public sector accounting scholars, practitioners and administrators in the process of adopting new accounting and budgeting practices.

The remainder of this editorial is structured into three main sections. Section 2 pinpoints unintended consequences of accounting and budgeting reforms in developing countries. Similarly, the importance of collaborative research in which practitioners and scholars could engage in mutually beneficial research projects is emphasised, as such a move would enable the introduction of accounting and budgeting practices in line with context specific peculiarities. Section 3 reviews the papers in this special issue. Finally, section 4 sheds light on directions for further studies.

\section{Unintended consequences of NPM reforms as a plea for engaged scholarship} Business-like practices, championed by professional accountants and consultants, are envisaged as better alternatives, if not the best, to replace the cash accounting and budgeting practices in central and local governments, and government-owned business entities. In developed countries, consultants, representing accounting firms, dominate the advocacy of business-like practices (Christensen and Skærbæk, 2010; Hellstrom and Lapsley, 2016), whilst international financial institutions and their representatives are instrumental in EEs (Dean, 1986a; Adhikari et al., 2013; Jayasinghe et al., 2021). One thing common in both jurisdictions is perhaps a limited account of the local context when recommending accrual accounting and other business-like accounting practices. Whereas the former group is unfamiliar with operational processes and working traditions in the government sector (Christensen and Skærbæk, 2010; Hellstrom and Lapsley, 2016), the latter group is ignorant about the traditions and politics in EEs and insufficiently aware of their needs, amongst other things (see Van Helden and Uddin, 2016; Hopper et al., 2017). As a result, the implementation process of reforms has been challenging. This section is devoted to underscoring unexpected consequences of NPM reforms and to shedding light on the need of adopting a new research approach in EEs.

\subsection{Unintended consequences of accounting and budgeting reforms}

Conventional accounting and budgeting practices in the public sector aim at controlling input and discharging budgetary accountability. Instead, NPM-based practices are concerned with accountability in terms of results and output, along with customer-like relationships (Hood, 1995; Hodges, 2012). Similarly, the traditional jargon of the public sector was replaced by terminologies such as managerialism, responsiveness, value for money, creativity and reengineering, amongst others (see Liddle, 2007). Such efforts do not take into account the need of facilitating the involvement of multiple stakeholders in the process of decision-making (Denhardt and Denhardt, 2000; Liddle, 2007; Torfing and Traintafillou, 2014; Steccolini, 2019). Planning Programming Budgeting (PPB) is one example. In the early 1970s, this budgeting model was proposed to avoid inefficiency in the government sector (Adhikari et al., 2013). Several Asian countries attempted to adopt PPB under the technical guidance of international institutions. India, Malaysia and the Philippines, Nepal and Sri Lanka, amongst other countries, were guided to rely upon PPB (Dean, 1986a).

Developing countries have earned a reputation of being pro-reformers. However, their intention has very often been to gain legitimacy and to continue receiving financial aid from international institutions and donor agencies. Political willingness to use such reforms for improving efficiency or accountability is either very low or non-existent (see Van Helden and Uddin, 2016; Hopper et al., 2017). The political motive behind the adoption of PPB could be to obtain legitimacy and foreign grants and aid (Adhikari et al., 2013). As a result, reforms adopted tend to wane or are superseded by new ideas as they evolve and are disseminated. 
Again, PPB was striking evidence as its adoption was driven by the political motive to obtain legitimacy and foreign grants and aid. For example, the Congress of the Philippines avoided enacting regulations to replace line item budgeting as revealed by Dean (1986a). In Nepal, it was experimented in certain ministries and abandoned as its implementation turned out to be technical and demanding, and far beyond the existing competence and capacity (Adhikari et al., 2013). In addition, the parliamentary oversight committees in many developing countries did not conduct their investigations based on PPB. The chairman of the Public Account Committee (PAC) in India had explained that $\mathrm{PPB}$ provided no useful information to conduct the committee's investigation (Dean, 1986a), whereas the members of the PAC in Sri Lanka did not possess competence to use information derived from PPB (Dean, 1986b). In addition, the existence of more than 2,000 pages in the budget and excessive numbers of pages for each ministry in India made it hard for legislators to use them (Dean, 1986a).

Following the trend of replacing cash-based accounting, some developing nations also made efforts to institutionalise accrual accounting. Such efforts have triggered conflicts between different professional groups on many occasions (Adhikari et al., 2013; Hopper et al., 2017). In Egypt, administrators with a native educational background undermined the implementation of suggestions made by Egyptians with a foreign degree (Adhikari et al., 2019). Similarly, the involvement of chartered accountants to promote and facilitate the introduction of accrual accounting in Bangladesh made both administrators and government accountants agitated and compelled them to resist or delay accounting reforms (Rajib et al., 2019). As demonstrated in the extant literature, the tendency to promote a one-size-fits all approach to accounting practices, disregarding the context and the competence and skills of administrators, has often failed (Van Helden and Uddin, 2016; Hopper et al., 2017). For example, all Indonesian local governments were ordered to present their financial statements as per accrual accounting from 2010. The lack of skilful administration was the main impediment to abide by this requirement and most local governments received a qualified audit opinion as elaborated by Boolaky et al. (2018). Similarly, the attempt to measure the performance of Tanzanian local authorities through financial reports has motivated them to offer money and other courtesy services to external performance assessors as a strategy of managing legitimacy (Gaspar and Mkasiwa, 2015). Goddard et al. (2016) state that financial statements of local authorities in Tanzania were stamped symbolically as "International Public Sector Accounting Standard (IPSAS) compliant" just to satisfy the funders and other supervisory bodies. That public sector accounting reforms have paradoxically allowed corruption, patronage, clientelism and neopatrimonialism to proliferate, rather than contributing to good governance and accountability is also evident in several countries in Africa (Bakre et al., 2017, 2021; Lassou, 2017).

The extant work shows that reforms initiated under the behest of NPM also do not take into account politics and power struggles, issues which characterise the public sector (Hopper et al., 2017), and are not concerned with the importance of fostering the constituents' involvement in planning and decision-making (see Denhardt and Denhardt, 2000; Liddle, 2007; Steccolini, 2019), at least at the grassroots level. Localised-led development discourses have been promoted more recently by international organisations, especially to address issues at grassroots levels. Participatory budgeting (PB) was central to localised-led development discourses, the significance of which was predicated on the assumption that its implementation would foster citizens' involvement in the planning process and offer them a space to make their voice heard on pressing issues impacting their lives and livelihoods (Ganuza and Baiocchi, 2012; Gonclaves, 2014; Saguin, 2018). However, the failure to consider the context-specific socio-political imperatives has largely impeded the potential of PB in garnering political emancipation for marginalised residents (Hopper et al., 2017; Saguin, 2018; Jayasinghe et al., 2020). Many PB initiatives in EEs have failed to live up to expectations, further eroding citizens' trust on governance. In particular, PB as a democratic governance 
JAEE 11,5

680 tool encountered several unanticipated consequences in yielding a democratic governance system at the grassroots level. Instead, specific groups could dominate the PB process (Kuruppu et al., 2016; Aleksandrov et al., 2018). For example, although PB aims at generating opportunities for marginalised groups to raise their voice, residential areas representing elites benefitted in Solo, Indonesia (Grillos, 2017). In other indigenous communities of Indonesia, members of these communities were forced to duplicate their budget process as part of complying with the ideas of PB promoted by international organisations (Jayasinghe et al., 2020). Similarly, as envisaged by Célérier and Botey (2015), the PB process was not a levelplaying field for underprivileged residents in Brazil also. All this context-based evidence underlies the importance of initiating collaboration between scholars and public administrators to identify and institutionalise accounting and budgeting practices compatible with politics and social traditions in the local contexts of EEs.

\subsection{A plea for engaged scholarship}

Universities are particularly concerned with teaching, research and disseminating knowledge. As such, academicians are offered freedom to conduct research that could be the trajectory of theory development and practice-relevant knowledge. However, some academicians have expressed their scepticism about the changing direction of accounting scholarships and their present state of affairs (Gendron, 2008; Van Helden and Northcott, 2010; Waymire, 2012; Zeff, 2019). Many accounting scholars prefer a hypothetico-deductive approach (Dyckman and Zeff, 2014, 2015) and may not aim to contribute to theory development. A number of scholars have raised their concerns, as the existing trend is likely to encourage conformist thinking and intellectual stagnation (Gendron, 2008; Waymire, 2012). As such, a plea is being made to adopt innovative methodological approaches that could contribute to regaining the relevance of accounting research (Kasanen et al., 1993; Gendron, 2008; Van Helden and Northcott, 2010; Waymire, 2012; ter Bogt and van Helden, 2014). The interventionist (constructive) research approach (IRA) could therefore be a good example in this regard.

As demonstrated in the literature, the IRA helps to develop a creative solution to a prevailing issue or problem and to exhibit its usability and theoretical connection, as well as to examine its potential for more general adequacy (Kasanen et al., 1993). Therefore, it potentially offers a greater scope to engage with practitioners and practice. For example, critical accounting scholars, representing EEs, are urged to engage with international financial institutions, such as the World Bank (WB) and International Monetary Fund (IMF), to show the influence of these institutions in triggering reforms and the manner in which such influences are operationalised (Hopper et al., 2017). More recently, Steccolini (2019) mentions that the extensive use of NPM both as a context of research and conceptual lens has put the discipline of public sector accounting into a golden cage, implying that NPM has given new life to public sector accounting research in terms of numbers of publications, but at the same time has contributed to limiting the growth of interdisciplinary and theoretically underpinned work. Mentions are therefore made emphasising the need of shifting the attention from the public sector to publicness (Bracci et al., 2021). It is argued that such a widening of the scope of public sector accounting research would rejuvenate the discipline, connecting it with public administration, policy and practice and theorising it within a wider social context.

When attempting to engage with other disciplines and practitioners, this requires collaboration and a dialectic process of inquiry, which points to a dialogue for identifying a research question that could meet the criteria of relevance in the academic and practitioner domain (ter Bogt and van Helden, 2014). Nevertheless, most of the published public sector accounting manuscripts aim at understanding management accounting practices in the government sector, and such studies may not necessarily represent the interests of practitioners (Van Helden and Northcott, 2010). Most practitioners are also not interested in 
academic research because either they do not have access to academic journals (Shapiro et al., 2007) or they are unaware of the available collaborative mechanisms with academics. Therefore, we appeal to scholars from EEs to adopt the IRA and search for a mechanism to engage in collaborative research with practitioners, policymakers and public administrators. Scholars need to be open-minded to thoughts from practice; they do have to take distance from ready-made solutions, as often propagated by consultants, and they need to invest a lot of time for getting to be trusted as appreciated partners for practitioners.

Engaged scholarship can be elaborated as a process of solving a problem or issue existing in a specific institution (ter Bogt and van Helden, 2011; Arnaboldi, 2013). In this approach, scholars, practitioners and administrators undertake research projects together. Therefore, this approach enables them to explore a practical, relevant research question(s) and access valuable data that may not be accessible otherwise (ter Bogt and van Helden, 2014). In other words, academic scholars can gain a broad understanding of contexts and tasks, including problems and issues in a selected social and institutional context (Van de Ven and Johnson, 2006; Crespo and Dridi, 2007; Arnaboldi, 2013). Similarly, knowledge derived through the collaboration is likely to be put into practice, as the administration is part of the process of proposing a new way of doing things (Van de Ven and Johnson, 2006; ter Bogt and van Helden, 2014). In addition, there is a trend to offer grants to increase cooperation between universities and private sector and public sector institutions and promote practice-relevant research (see Gulbrandsen and Smeby, 2005; Crespo and Dridi, 2007). It is therefore important for researchers to take a lead in facilitating collaborative work and help address social problems and issues (see Shapiro et al., 2007; ter Bogt and van Helden, 2012). Otherwise, failure to take heed of this expectation will mean that the legitimacy of scholars will be undermined (Shapiro et al., 2007). As envisaged by scholars, engaged scholarship has not impeded critical research and publishing it in good journals (Crespo and Dridi, 2007; ter Bogt and van Helden, 2011, 2012). As such, we encourage accounting scholars from EEs to adopt the IRA that would contribute to fostering cooperation with the administration and practice whilst enabling the founding of locally developed accounting and budgeting practices.

\section{The papers in this special issue}

Until now, the JAEE has only published a relatively small number of papers in the realm of public sector accounting, that is, approximately $10 \%$ of the total number of published papers. This special issue aims to give a boost to this niche domain because the large extent and impact of the public sector in EEs merits increasing research efforts about accounting in this sector. Moreover, a review of public sector accounting research in the JAEE, as published in this special issue (van Helden et al., 2021; this issue), points to the absence of literature reviews and of empirical papers originating in South America. In these respects, this special issue fills the indicated gaps through the inclusion of two literature reviews - one about public sector accounting research in EEs, as published in the JAEE, and one about gender budgeting in EEs - and additionally by a paper about efficiency in a public utility in Colombia. The remaining three papers are empirical investigations originating in Africa (Ghana, Nigeria and South Africa). Three of the empirical studies - those from the African continent and the earlier indicated paper from Colombia -rely on an interpretive paradigm and the use of qualitative methods, while one paper is based on a positivist paradigm and the use of quantitative methods. This section further summarises the papers in this special issue.

The first literature review is about public sector accounting research, as published in the JAEE's first decade (van Helden et al., 2021; this issue). It shows that NPM dominates the research, with performance management, budgeting and accrual accounting as the main accounting topics. The review also reveals that NPM claims, which can range from usability and use of a new accounting repertoire, to desirable impacts on efficiency and service 
JAEE 11,5

682

delivery, are often not fulfilled. Failing accounting innovations are often caused by contextual factors, such as political instability, poor governance and a lack of capabilities. A variety of theoretical perspectives are mobilised in the reviewed research, and neo-institutional theory is the most popular theoretical stance. The reviewed research is positioned in the context of extant knowledge in this domain. This review recommends future research that moves away from a focus on public sector accounting reforms and to concentrate instead on an understanding of how the accounting repertoire works in practice, including routes for potential improvements therein. In addition, future research is propagated that goes beyond NPM thinking, by focussing on accounting for strengthening the collective well-being in a society and enhancing democratic values.

The other literature review deals with gender budgeting in EEs (Nolte et al., 2021; this issue). More than 80 countries have adopted some elements of gender budgeting, and in recent years, the topic has drawn the increasing attention of researchers, policymakers and international organisations. An ultimate aim of gender budgeting has been to ensure that government budgets promote greater gender equality, and that equality policies are embedded in the discharging of government accountability. The review paper discusses both the literature emerging in this field and the avenues for future research. The result of the review demonstrates relatively few publications on this topic and almost a non-existence of papers on gender budgeting in accounting journals. The majority of the published articles on this topic have adopted a case study approach, and almost $40 \%$ of the papers reviewed have been focused on preparatory and approval phases of gender budgeting. The review also demonstrates the non-existence of empirical comparative analysis of the contextual factors of gender budgeting. Relatively little is known about how different socio-political, economic and cultural contexts influence gender budgeting design and implementation. The review paper has urged researchers to facilitate more analytical works on the topic drawing on primary data. Similarly, the execution and the auditing of gender budgeting represent other areas, which could be explored in further studies. The need for studying gender budgeting through accounting perspectives, as well as developing a sequential approach to implementation, is outlined in the paper.

The first empirical study in this special issue is a field study on public sector financial management reforms in Ghana relying on insights from neo-institutional theory (Tetteh et al., 2021, this issue). More particularly, this study discusses the adoption, implementation and use of an integrated financial management information system in various governmental institutions, and evidence mainly comes from interviews with Ghana's controllers and accountant general department, in addition to relevant documents. The study shows that coercive, normative and mimetic pressures have affected the adoption and implementation of this system, but internal factors, such as top management support and strong technical support, were also facilitating the reform. However, the ultimate use of this new system was limited, predominantly due to a lack of information-technological skills of top bureaucrats, an inadequate information technology infrastructure and resistance from users. The outcomes of this study stand out because, despite the fact that various conditions for a successful financial management reform were fulfilled, the usage stage of the reform was constrained by both technical and cultural influences. This paper could be important to other EEs that aim to enact a governmental financial management reform because it offers a blueprint of factors to be taken into account.

The second empirical paper originates from Colombia and investigates how a state-owned multi-utility conglomerate (CMC) has used different management accounting practices, including accrual accounting, in its attempt to achieve efficiency (Álvarez et al., 2021). Giddens' structuration theory has been used to demonstrate the interplay between structure and agency taking place in the process of operationalising efficiency. This is an interpretative study, and the data have been derived from interviews, non-participative observations and document analysis. 
Accrual accounting was introduced to Colombian multi-utility conglomerate (CMC) three decades prior to its dissemination in Western countries as part of NPM. As a result, the operating structure, mind-set and agency of the managers and staff members at CMC were already set up in line with neoliberal market principles. In particular, the paper has shown the important role that the School of Mines has played in shaping agency and making efficiency a corporate value. NPM offered CMC further space and opportunity to experiment several NPM-propagated accounting technologies and reproduce the notion of efficiency. The company developed and pursued a longterm financial approach though the use of several management accounting practices. A key contribution of the study concerns demonstrating the capacity of management accounting practices in constructing and operationalising the notion of efficiency. Theoretically, the study has demonstrated the empirical significance of structuration theory in EE contexts. However, the way in which structure and agency are embedded in management accounting practices may vary across contexts; further studies are therefore called for covering other EEs.

The third paper based on empirical research is a qualitative study about risk management systems in public sector procurement processes in a South African state-owned enterprise (Myeza et al., 2021, this issue). This study is based on interviews with management advisors, forensic investigators and auditors. Corruption and unethical behaviour in public sector procurement processes are major problems in South Africa, as well as in other countries in both the developed and underdeveloped world. So, the paper addresses a problem of large practical relevance. This study applies the Committee of Sponsoring Organizations (COSO) framework for investigating which control principles can be of importance in procurement processes. Accordingly, it makes a distinction between the following control principles: governance and culture; strategy and objective setting; performance; review and revision; and information, communication and reporting. The paper points to failing risk management systems, and it concludes that an involvement of both the political and executive top levels is largely conducive to these failing systems.

The final paper in this special issue is a quantitative study on fraud detection in the Nigerian public sector (Oyerogba, 2021, this issue). This study investigates various forensic auditing mechanisms, especially relevant knowledge, skills, tools and expertise, and it seeks to examine whether these mechanisms can explain the extent of fraud detection. The distinctiveness of this study is that it relies on a survey amongst a broad spectrum of stakeholders in forensic auditing in the governmental sector, particularly judges, governmental officials, auditors and scholars. The findings, on the one hand, indicate which types of forensic knowledge, skills, tools and expertise are valued by the respondents. On the other hand, they reveal that forensic knowledge, skills and tools explain fraud detection, but expertise does not. This is derived from the application of a variety of regression analyses, which contribute to the robustness of the findings. Because fraud is a major problem in both developed and less developed countries, including Nigeria, the practical relevance of this type of research is without doubt; it gives pointers for the development of fraud mechanisms, which can be conducive to government policies and curricula for forensic auditing training programmes.

\section{Directions for future research}

Although the various papers in this special issue already provide pointers for interesting further research, this final section of our editorial discusses some more general directions for future research, which we want to connect to the discussion about challenging themes in the literature on public sector accounting.

Our first suggestion for future research is concerned with the role of academic researchers in conducting scholarly work. The review of the public sector accounting research published in the first decade of the JAEE indicates that many studies conclude that public sector 
JAEE 11,5

684 accounting reform attempts do not live up to their promises (van Helden et al., 2021; this issue). This is corroborated in other public sector accounting reviews (Van Helden and Uddin, 2016; Lapsley and Miller, 2019). This finding puzzles us in many respects. Do we need to search for other research designs, for example, by conducting comparative studies, which search for the antecedents of both successes and failures of public sector accounting innovations (Adhikari et al., 2019)? Or, do we have to convince practitioners to move away from a one-size-fits-all reform repertoire (see section 3)? A more fundamental answer comes from a reconsideration of our role as outsiders of public sector accounting practices. We, as researchers, are investigating these practices without a strong commitment to the improvement of them. An alternative role could be acting as engaged scholars, that is, taking part in change processes in practice, helping practitioners in solving their problems, but at the same time protecting our main scholarly role as impartial and critical observers of practices (Van de Ven and Johnson, 2006). We acknowledge that it will not be easy combining these roles. Nevertheless, some more concrete suggestions can be provided. Scholars could, for example, take part in advisory committees for developing reforms at the sector level, such as for municipalities or for organisations in the healthcare sector. Here, their role could focus on establishing what conditions are needed for making certain reforms potentially successful, in terms of capabilities, resources and a mitigation of cultural hindrances. Academic researchers can also take up a role in interventionist research, in which they collaborate with practitioners to develop and implement specific accounting changes that seriously take account of context-specific aspects (see ter Bogt and van Helden, 2011, for a public sector accounting illustration; see also our recommendation at the end of section 2).

Recent debates about emerging themes in public sector accounting give rise to issues beyond more or less traditional themes revolving around the budgetary cycle, such as cash versus accrual accounting for financial reporting, performance budgeting and costing of services. These emerging issues on the one hand concern innovations in budgeting, such as participatory budgeting (see the literature review in this issue; van Helden et al., 2021) and gender budgeting (see the literature review on this theme in this issue; Nolte et al., 2021). On the other hand, emerging themes regard accounting for wicked problems, coproduction, financial resilience, and public value and publicness. We do not see these new themes in this special issue and neither in the public sector accounting papers that have been published in this journal's first decade. So, future research on these new themes in the context of EEs is desirable. More specific suggestions are given below.

Wicked problems are problems that lack a clear understanding of their scope and possible solutions. Such problems require broad ways of thinking about variables, options and linkages, which may give rise to debates amongst actors to achieve temporary compromises, while the underlying differences may persist (Head and Alford, 2015, p. 722). Jacobs and Guganesan (2014) refer to the practical relevance of wicked problems that due to their complexity, dynamics, and the involvement of multiple stakeholders, require a multidisciplinary approach. Complex city-centre projects could, for example, imply the involvement of disciplines like spatial planning, architecture, public administration and accounting. Within the context of EEs, long-term development projects often include a multiplicity of functions, such as education, physical and medical infrastructure as well as economic facilities for local citizens. As a consequence, they require the engagement of a variety of stakeholders, including local communities, NGOs, governments and international development institutions. Accounting can probably play a facilitating role in tackling and debating wicked problems, rather than a problem-solving role, that is, it could provide ammunition for the support of these debates in the form of, for instance, financial and other impacts concerning a variety of scenarios.

Coronavirus disease 2019 (COVID-19) has led to the rethinking of the way public services are delivered. Two issues are worth mentioning in this regard. Firstly, with years of austerity, 
budget cuts and resource constraints, public trust in governments has eroded across countries. Both governments' capacities and capabilities of handling the consequences of the pandemic have therefore drawn greater attention. Next, COVID-19 has exposed the heterogeneity of our societies (Bracci et al., 2021) and the deeply rooted social inequality, injustice and entrenched disadvantages at grassroots levels (O'Flynn, 2020). The concept of coproduction has increasingly been envisaged as an alternative in pursuing policy reforms and service delivery (Bovaird, 2007; Nabatchi et al., 2017; Steccolini, 2019). Coproduction involves both users and public sector professional in different stages of policymaking and streamlining the quality and quantity of public services. However, little research has been undertaken so far delineating the way public sector accounting has been implicated in the operationalisation of coproduction in developed countries, let alone EEs.

The term "financial resilience" has been applied in management and other disciplines to study how a system reacts to exogenous shocks and disturbances and how it recovers and adapts to new circumstances (Linnenluecke, 2017; Upadhaya et al., 2020). While few public sector scholars have applied the resilience perspective to shed light on governments' responses to financial crises (see e.g. Barbera et al., 2017, 2020), the significance of this perspective has been particularly emphasised in EE contexts to analyse the consequences of governments' responses to the pandemic, taking into account their anticipatory and coping capacities (Upadhaya et al., 2020). In the aftermath of the pandemic and within the context of limited public resources and rising budgetary expenditures, the objective of public sector accounting has been expanded, including building resilience. Governments can only safeguard their economies and protect people's livelihoods if they are able to anticipate, absorb and react to future shocks. What role public sector accounting can play in building on financial resilience and responding to shocks and crises may therefore represent an interesting direction for future research in EEs.

Our research tradition is very much impacted by economic thinking, in which labels like economy, efficiency, effectiveness and accountability are core. As a result, accounting techniques such as accrual accounting and IPSASs, performance measurement and various other management accounting tools continue to dominate public sector accounting research, and also in EEs. As is the case in Western countries, these techniques and tools have been seen as a means through which to make such goals (i.e. efficiency, effectiveness and accountability) visible, as well as to prioritise issues such as outputs, results and outcomes in resource allocation and service delivery (Bracci et al., 2021). This is also reflected in the papers in this special issue, such as the influence of NPM on public sector accounting research (van Helden et al., 2021; this issue), as well as the usability of advanced financial management systems (Tetteh et al., 2021, this issue), and the availability of mechanisms for tackling fraud (Oyerogba, 2021, this issue). The emerging attention for public value and publicness takes distance from this economic way of thinking and aims to elevate the specific values of the public sector, such as fairness, accessibility of services for many groups of citizens, including the less privileged ones, sustainability of service production and consumption, and accountability of governments towards a broad spectrum of stakeholders (Steccolini, 2019; Bracci et al., 2021). According to Bracci et al. (2021), combinations of logics, for example, an economic logic and a professional logic (such as originating in a medical or cultural profession), can lead to new forms of accounting that not only facilitate certain changes but also shape these changes.

In the context of EEs, accounting systems can accommodate the values of both rational government and kinship in local communities (Goddard et al., 2016; Phiri and Guven-Uslu, 2018). In a more general vein, accounting can be supportive to identifying measurable constructs for a multitude of values that are core to public sectors in EEs. To some extent, this has been discussed in the literature (see van Helden et al., 2021, this issue; Hopper et al., 2009; 
JAEE 11,5

686
Van Helden and Uddin, 2016). For instance, Van Helden and Uddin (2016) discuss a shift in the development discourses of international organisations to EEs and corresponding alternation in public sector accounting and accountability. While still propagating neoliberal NPM values such as free market and private ownership, a new agenda, localised-led development, has been advanced as a way forward in rectifying the failure of market-led development discourses. At the heart of the new agenda lies the reinvention of democracy at the grassroots level by eradicating all forms of racial, gender and ethnic discrimination, corruption and political patronage. The localised-led development logics are constructed accepting the emancipatory role of accounting in terms of constructing a more democratic, participative and social form of accountability (Alawattage and Azure, 2021). An important avenue for future public sector accounting research could therefore be the exploration of the way in which accounting is implicated in localised-led development, and how local issues such as public participation, emancipation and social accountability are better addressed through accounting.

We hope this special issue will trigger the interest of public sector accounting researchers in EEs and beyond to explore new research topics and contexts and further enrich our understanding and theorisation of existing accounting practices and ongoing reforms. This editorial review is just one example showing that there are so many accounting issues that are underexplored; insights into these issues are of paramount importance to set up future directions for public sector accounting research in EEs and beyond.

Chamara Kuruppu USN School of Business, University of South-Eastern Norway, Notodden, Norway

Pawan Adhikari Essex Business School, University of Essex, Colchester, UK, and

Jan van Helden University of Groningen, Groningen, The Netherlands

\section{References}

Adhikari, P., Kuruppu, C. and Matilal, S. (2013), "Dissemination and institutionalization of public sector accounting reforms in less developed countries: a comparative study of the Nepalese and Sri Lankan central governments", Accounting Forum, Vol. 37 No. 3, pp. 213-230.

Adhikari, P., Kuruppu, C., Wynne, A. and Ambalangodage, D. (2015), "Diffusion of the cash basis international public sector accounting standard (IPSAS) in less developed countries (LDCs) the case of the Nepali central government”, in Jayasinghe, K., Nath, N. and Othman, R. (Eds), The Public Sector Accounting, Accountability and Auditing in Emerging Economies, Emerald, Bingley, pp. 85-108.

Adhikari, P., Kuruppu, C., Ouda, H., Grossi, G. and Ambalangodage, D. (2019), "Unintended consequences in implementing public sector accounting reforms in emerging economies: evidence from Egypt, Nepal and Sri Lanka”, International Review of Administrative Sciences. doi: $10.1177 / 0020852319864156$.

Alawattage, C. and Azure, J. (2021), "Behind the World Bank's ringing declarations of 'social accountability': Ghana's public financial management reform”, Critical Perspectives on Accounting, Vol. 78, p. 102075.

Aleksandrov, E., Bourmistrov, A. and Grossi, G. (2018), "Participatory budgeting as a form of dialogic accounting in Russia: actors' institutional work and reflexivity trap", Accounting, Auditing and Accountability Journal, Vol. 31 No. 4, pp. 1098-1123.

Álvarez, C.B., Adhikari, P. and Gómez Mejía, A. (2021), "Management accounting practices and efficiency in a Colombian multi-utility conglomerate", Journal of Accounting in Emerging Economies, Vol. 11 No. 5, pp. 714-734. 
Arnaboldi, M. (2013), "Consultant-researcher in public sector transformation: an evolving role", Financial Accountability and Management, Vol. 29 No. 2, pp. 140-160.

Bakre, O., Lauwo, S. and McCartney, S. (2017), "Western accounting reforms and accountability in wealth redistribution in patronage-based Nigerian society", Accounting, Auditing and Accountability Journal, Vol. 30 No. 6, pp. 1288-1308.

Bakre, O., McCartney, S. and Fayemi, S. (2021), "Accounting as a technology of neoliberalism: the accountability role of IPSAS in Nigeria”, Critical Perspectives on Accounting. doi: 10.1016/j.cpa. 2020.102282 .

Barbera, C., Jones, M., Korac, S., Saliterer, I. and Steccolini, I. (2017), “Governmental financial resilience under austerity in Austria, England and Italy: how do local governments cope with financial shocks?”, Public Administration, Vol. 95 No. 3, pp. 670-697.

Barbera, C., Guarini, E. and Steccolini, I. (2020), "How do governments cope with austerity? The roles of accounting in shaping governmental financial resilience", Accounting, Auditing and Accountability Journal, Vol. 33 No. 3, pp. 529-558.

Boolaky, P.K., Mirosea, N. and Singh, K. (2018), "On the regulatory changes in government accounting development in Indonesia: a chronology from colonization and photoionization era", Journal of Accounting in Emerging Economies, Vol. 8 No. 3, pp. 387-411.

Bovaird, T. (2007), "Beyond engagement and participation: user and community coproduction of public services", Public Administration Review, Vol. 67 No. 5, pp. 846-860.

Bracci, E., Saliterer, I., Sicilia, M. and Steccolini, I. (2021), "Accounting for (public) value(s): reconsidering publicness in accounting research and practice", Accounting, Auditing and Accountability Journal, Vol. 34 No. 7, pp. 1513-1526.

Célérier, L. and Botey, L. (2015), "Participatory budgeting at a community level in Porto Alegre: a Bourdieusian interpretation", Accounting, Auditing and Accountability Journal, Vol. 28 No. 5, pp. 739-772.

Christensen, M. and Parker, L. (2010), "Using ideas to advance professions: public sector accrual accounting", Financial Accountability and Management, Vol. 26 No. 3, pp. 246-266.

Christensen, M. and Skærbæk, P. (2010), "Consultancy outputs and the purification of accounting technologies", Accounting, Organizations and Society, Vol. 35, pp. 524-545.

Christensen, M., Newberry, S. and Potter, B. (2019), "Enabling global accounting change: epistemic communities and the creation of a "more business-like' public sector", Critical Perspectives on Accounting, Vol. 58, pp. 53-76.

Crespo, M. and Dridi, H. (2007), "Intensification of university-industry relationships and its impact on academic research", Higher Education, Vol. 54, pp. 61-84.

Dean, P.N. (1986a), “Assessing the performance budgeting experiment in four developing countries”, Financial Accountability and Management, Vol. 2 No. 1, pp. 1-24.

Dean, P.N. (1986b), "Performance budgeting in Sri Lanka", Public Budgeting and Finance, Vol. 6 No. 2, pp. 63-75.

Dean, P.N. (1989), “Accounting for development projects: the issues", Financial Accountability and Management, Vol. 5 No. 3, pp. 135-147.

Denhardt, R.B. and Denhardt, J.V. (2000), "The new public service: serving rather than steering", Public Administration Review, Vol. 60 No. 6, pp. 549-559.

Dyckman, T.R. and Zeff, S.A. (2014), "Some methodological deficiencies in empirical research articles in accounting", Accounting Horizons, Vol. 28 No. 3, pp. 695-712.

Dyckman, T.R. and Zeff, S.A. (2015), "Accounting research: past, present and future”, Abacus, Vol. 51 No. 4, pp. 511-524.

Gårseth-Nesbakk, L. and Kuruppu, C. (2018), "Diametrical effects in governmental accountability - the auditor general's struggle to sustain balance in performance auditing reports and media disclosure", Pacific Accounting Review, Vol. 30 No. 3, pp. 274-296. 
JAEE 11,5

688

Ganuza, E. and Baiocchi, G. (2012), "The power of ambiguity: how participatory budgeting travels the globe", Journal of Public Deliberation, Vol. 8 No. 2, pp. 1-12, (Article. 8).

Gaspar, A.F. and Mkasiwa, T.A. (2015), "Managing performance or legitimacy? A case study of the Tanzanian Local Government Authorities", Journal of Accounting in Emerging Economies, Vol. 5 No. 4, pp. 424-456.

Gendron, Y. (2008), "Constituting the academic performer: the spectre of superficiality and stagnation in academia", European Accounting Review, Vol. 17 No. 1, pp. 97-127.

Goddard, A., Assad, M., Issa, S., Malagilla, J. and Makasiwa, T.A. (2016), "The two publics and institutional theory - a study of public sector accounting in Tanzania", Critical Perspectives on Accounting, Vol. 40, pp. 8-25.

Goncalves, S. (2014), "The effects of participatory budgeting om municipal expenditures and infant mortality in Brazil", World Development, Vol. 53, pp. 94-110.

Grillos, T. (2017), "Participatory budgeting and the poor: tracing bias in a multi-staged process in Solo, Indonesia”, World Development, Vol. 96, pp. 343-358.

Gulbrandsen, M. and Smeby, J. (2005), "Industry funding and university professors' research performance", Research Policy, Vol. 34, pp. 932-950.

Head, B.W. and Alford, J. (2015), "Wicked problems: implications for public policy and management", Administration and Society, Vol. 47 No. 6, pp. 711-739.

Hellstrom, C. and Lapsley, I. (2016), "Humour and happiness in an NPM world: do they speak in jest?", Critical Perspectives on Accounting, Vol. 27, pp. 51-64.

Hodges, R. (2012), "Joined-up government and the challenges to accounting and accountability researchers", Financial Accountability and Management, Vol. 28 No. 1, pp. 26-51.

Hood, C. (1991a), "A public management for all seasons", Public Administration, Vol. 69, pp. 3-19.

Hood, C. (1991b), "The new public management in the 1980s: variation on a theme", Accounting, Organizations and Society, Vol. 20 Nos 2/3, pp. 93-109.

Hood, C. (1995), "The 'new public management', in the 1980s: variations on a theme", Accounting, Organizations and Society, Vol. 20 Nos 2/3, pp. 93-109.

Hopper, T., Tsamenyi, M., Uddin, S. and Wickramasinghe, D. (2009), "Management accounting in less developed countries: what is known and needs knowing", Accounting, Auditing and Accountability Journal, Vol. 22 No. 3, pp. 469-514.

Hopper, T., Lassou, P. and Soobaroyen, T. (2017), "Globalisation, accounting and developing countries", Critical Perspectives on Accounting, Vol. 43, pp. 125-148.

Hyndman, N., Liguori, M., Meyer, R.E., Polzer, T., Rota, S. and Seiwald, J. (2014), “The translation and sedimentation of accounting reforms: a comparison of the UK, Austrian and Italian experiences", Critical perspectives on Accounting, Vol. 25, pp. 388-408.

Jacobs, K. and Guganesan, S. (2014), "Interdisciplinary accounting research in the public sector dissolving boundaries to tackle wicked problems", Accounting, Auditing and Accountability Journal, Vol. 27 No. 8, pp. 1250-1256.

Jayasinghe, K., Adhikari, P., Carmel, S. and Sopanah, A. (2020), "Multiple rationalities of participatory budgeting in Indigenous communities: evidence from Indonesia", Accounting Auditing and Accountability Journal, Vol. 33 No. 8, pp. 2139-2166.

Jayasinghe, K., Adhikari, P., Wynne, A., Malagila, J., Abdurafiu, N. and Soobaroyen, T. (2021), "Government accounting reforms in Sub-Saharan African countries and the selective ignorance of the epistemic community: a competing logics perspective", Critical Perspectives on Accounting, Vol. 78, pp. 1-22.

Kasanen, E., Lukka, K. and Siitonen, A. (1993), "The constructive approach in management accounting research", Journal of Management Accounting Research, Vol. 14, pp. 243-264. 
Kuruppu, C., Adhikari, P., Gunarathne, V., AmbalangodagePerera, D.P. and Karunarathne, C. (2016), "Participatory budgeting in a Sri Lankan urban council: a practice of power and domination", Critical Perspectives on Accounting, Vol. 41, pp. 1-17.

Lapsley, I. and Miller, P. (2019), "Transforming the public sector: 1998-2018”, Accounting, Auditing and Accountability Journal, Vol. 32 No. 8, pp. 2211-2252.

Lassou, P. (2017), "State of government accounting in Ghana and Benin: a 'tentative' account", Journal of Accounting in Emerging Economies, Vol. 7 No. 4, pp. 486-506.

Liddle, J. (2007), "Challenges to democratic legitimacy, scrutiny, accountability in the UK national and local state", Public Administration Quarterly, Vol. 31 No. 4, pp. 397-428.

Linnenluecke, M.K. (2017), "Resilience in business and management research: a review of influential publications and a research agenda", International Journal of Management Reviews, Vol. 19 No. 1, pp. 4-30.

Myeza, L., Nkhi, N. and Maroun, W. (2021), "Risk management factors contributing to transgressions in the procurement practices in South African SOEs", Journal of Accounting in Emerging Economies, Vol. 11 No. 5, pp. 735-751.

Nabatchi, T., Sancino, A. and Sicilia, M. (2017), "Varieties of participation in public services: the who, when and what of coproduction", Public Administration Review, Vol. 77 No. 5, pp. 766-776.

Nolte, I.M., Polzer, T. and Seiwald, J. (2021), "Gender budgeting in emerging economies-a systematic literature review and research agenda”, Journal of Accounting in Emerging Economies, Vol. 11 No. 5 , pp. $799-820$.

O'Flynn, J. (2020), “Confronting the big challenges of our time: making a difference during and after COVID-19", Public Management Review, Vol. 23 No. 7, pp. 961-980.

Oyerogba, E.O. (2021), "Forensic auditing mechanism and fraud detection: the case of Nigerian public sector", Journal of Accounting in Emerging Economies, Vol. 11 No. 5, pp. 752-775.

Phiri, J. and Guven-Uslu, P. (2018), "Institutional pluralism, two publics theory and performance reporting practices in Zambia's health sector", Journal of Accounting in Emerging Economies, Vol. 8 No. 1, pp. 141-162.

Rajib, S.U., Adhikari, P., Hoque, M. and Akter, M. (2019), "Institutionalisation of the cash basis international public sector accounting standard in the central government of Bangladesh: an example of delay and resistance", Journal of Accounting in Emerging Economies, Vol. 9 No. 1, pp. 28-50.

Saguin, K. (2018), "Why the poor do not benefit from community-driven development: lessons from participatory budgeting", World Development, Vol. 112, pp. 220-232.

Shapiro, D.L., Kirkman, B.L. and Courtney, H.G. (2007), "Perceived causes and solutions of the translation problem in management research", The Academy of Management Journal, Vol. 50 No. 2, pp. 249-266.

Steccolini, I. (2019), "Accounting and the post-new public management: re-considering publicness in accounting research", Accounting, Auditing and Accountability Journal, Vol. 32 No. 1, pp. 255-279.

Steccolini, I., Bracci, E., Saliterer, I. and Sicilia, M.F. (2021), "Accounting for (public) value(s): reconsidering publicness in accounting research and practice", Accounting Auditing and Accountability Journal. doi: 10.1108/AAAJ-06-2021-5318.

ter Bogt, H. and van Helden, J. (2011), "The role of consultant-researchers in the design and implementation process of a programme budget in a local government organization", Management Accounting Research, Vol. 22, pp. 56-64.

ter Bogt, H. and van Helden, J. (2012), "The practical relevance of management accounting research and the role of qualitative methods therein", Management Accounting Research, Vol. 9 No. 3, pp. 265-295. 
JAEE 11,5 ter Bogt, H. and van Helden, G.J. (2014), "A pragmatic view on engaged scholarship in accounting research", Qualitative Research in Accounting and Management, Vol. 11 No. 1, pp. 40-50.

Tetteh, L.A., Agyenim-Boateng, C., Simpson, S.N.Y. and Susuawu, D. (2021), "Public sector financial management reforms in Ghana: insights from institutional theory", Journal of Accounting in Emerging Economies, Vol. 11 No. 5, pp. 691-713.

Torfing, J. and Traintafillou, P. (2014), "What's in a name? Grasping new public governance as a political-administrative system", International Review of Public Administration, Vol. 18 No. 2, pp. 9-25.

United Nations (1984), Accrual Accounting in Developing Countries, United Nations, New Yourk.

Upadhaya, B., Wijethilake, C., Adhikari, P., Jayasinghe, K. and Arun, T. (2020), "COVID-19 policy responses: reflections on governmental financial resilience in South Asia", Journal of Public Budgeting Accounting and Financial Management, Vol. 32 No. 5, pp. 825-836.

Van de Ven, A.H. and Johnson, P.E. (2006), "Knowledge for theory and practice", Academy of Management Review, Vol. 31 No. 4, pp. 802-821.

Van Helden, G.J. and Northcott, D. (2010), "Examining the practical relevance of public sector management accounting research", Financial Accountability and Management, Vol. 26 No. 2, pp. 213-240.

Van Helden, J. and Uddin, S. (2016), "Public sector management accounting in emerging economies: a literature review", Critical Perspectives in Accounting, Vol. 41, pp. 34-62.

van Helden, J., Adhikari, P. and Kuruppu, C. (2021), "Public sector accounting in emerging economies: a review of the papers published in the first decade of Journal of Accounting in Emerging Economies", Journal of Accounting in Emerging Economies, Vol. 11 No. 5, pp. 776-798.

Waymire, G.B. (2012), "Seeds of innovation in accounting scholarship", Issues in Accounting Education, Vol. 27 No. 4, pp. 1077-1093.

World Bank (2020), Global Economic Prospects, the World Bank Group, Washington DC.

Zeff, S.A. (2019), "A personal view of the evolution of the accounting professoriate", Accounting Perspectives, Vol. 18 No. 3, pp. 159-185. 